\title{
IMPLEMENTASI ALGORITMA LEVENSHTEIN DISTANCE DENGAN RESTFUL WEB SERVICE PADA KATA BAHASA INDONESIA KE BAHASA JAWA BERBASIS WEB
}

\author{
Welly Kuswanto \\ Prodi teknik informatika,STIKI Malang \\ Email:Wellykuswanto@gmail.com
}

(Naskah masuk: 14 Juni 2020, diterima untuk diterbitkan: 27 Juni 2020)

\begin{abstract}
ABSTRAK
Bahasa Indonesia yang selelu kita pakai menjadi bahasa persatuan di Indonesia. Disamping bahasa persatuan, Indonesia juga memiliki banyak bahasa daerah salah satunya adalah bahasa Jawa. Semua warga negara Indonesia tentunya terbiasa dalam berbahasa Indonesia karena Bahasa Indonesia adalah Bahasa nasional. Namun dalam berkomunikasi bahasa daerah seperti bahasa Jawa, masyarakat tidak terbiasa menggunakan Bahasa Jawa dibandingkan bahasa Indonesia terutama masyarakat yang tinggal di pulau Jawa. Hal ini dikarenakan masyarakat jawa terbiasa berbahasa Indonesia dibandingkan dengan berbahasa Jawa. Oleh karena itu, penulis mencoba membangun sistem untuk mempermudah pengembang aplikasi dengan tujuan agar efektif dan efisien dalam mengembangkan aplikasinya tanpa memandang berbagai platform dan bahasa pemrograman yang digunakan. Hal ini bertujuan untuk menyediakan komunikasi online yang menyenangkan disaat terjadi pandemic Corona Virues Disease 2019 (COVID 19) di Indonesia khususnya di pulau jawa. Efek langung yang dirasakan pada saat pandemi COVID 19 adalah semua pekerja mengimplementasikan komunikasi via dalam jaringan (daring/online) terkait dengan urusan kantor. Hal ini menyebabkan penulis menyediakan media komunikasi yang inovatif dalam bahasa Jawa, maka dibuatlah api (web service), serta menggunakan metode levenshtein distance dalam pencocokan kata bahasa Indonesia sebelum diterjemahkan ke bahasa Jawa. Web service yang dirancang mengunakan susunan restfull web service. Hasil aplikasi menggunakan metode approximate string matching didapatkan hasil persentase nilai precision sebesar $95,32 \%$, nilai recall $100 \%$, nilai accuracy $99,97 \%$, dan nilai $f$-measure $97,51 \%$. berdasarkan input sumber dan output target sangat efektif karena mendapatkan persentase yang cukup tinggi. tidak terdapat banyak kesalahan pada saat proses, sehingga secara fungsional dapat menampilkan hasil yang yang diinginkan.
\end{abstract}

Kata kunci: Web Service, levenshtein distance, Bahasa Indonesia, Bahasa Jawa.

\begin{abstract}
Indonesian which is always used as a union language. Besides of it, Indonesia has many regional languages, one of which is Javanese. All Indonesian citizens are naturally accustomed to speaking Indonesian because Indonesian is the national language. However, in communicating local languages such as Javanese, Indonesian society are not accustomed to using Javanese compared to Indonesian, especially people who live on the Java Island. This condition caused by Javanese people are accustomed to speak Indonesian compared to Javanese. Therefore, the writer tries to build a system to facilitate developers with the aim to be effective and efficient in developing applications regardless of the various platforms and programming languages used. It aims to provide pleasant online communication when the pandemic Corona Virus Disease 2019 (COVID 19) occurs in Indonesia, especially on the Java Island. The immediate effect felt during the COVID 19 pandemic is that all workers implement online communication related to their jobs. This condition causes the writer to provide innovative communication media in Javanese, create Application Programming Interface (web service), and uses levenshtein distance method in matching Indonesian words before translating to Javanese. Web service designed using a restful web service arrangement. The results of the application using the approximate string matching method obtained the percentage of precision values of $95.32 \%, 100 \%$ recall value, $99.97 \%$ accuracy value, and f-measure value $97.51 \%$. Based on source input and target output is very effective because it gets a high percentage. There are not many errors during the process, so it can functionally display the desired results.
\end{abstract}


Keywords: Web Service, Levenshtein Distance, Indonesian, Javanese.

\section{PENDAHULUAN}

Jati diri sebuah bangsa bisa dilihat dari segi bahasa, seperti halnya bahasa Indonesia yang digunakan sebagai bahasa nasional (Rifa'i, 2015). Bahasa persatuan atau bahasa Indonesia mempunyai peran penting disemua aspek kehidupan bersosialisasi dalam hal berkomunikasi dengan masyarakat. Selain mempunyai bahasa persatuan (Arisandy et al., 2019), Indonesia juga mempunyai berbagai bahasa daerah, diantaranya bahasa Jawa.

Bahasa Jawa adalah suatu Bahasa daerah yang perannya dituturkan oleh penduduk bagian tengah dan timur pulau jawa dan merupakan kebudayaan dari Indonesia sejak pendaratan penduduk astronesia tepatnya di pantai utara jawa (Noerwidi, 2008), akan tetapi komunikasi dalam Bahasa jawa dirasa kurang sebanding dengan fakta yang ada. Karena masyarakat jawa sendiri lebih banyak berbahasa Indonesia dari pada berbahasa jawa. Sarana yang bisa menjembatani pada masyarakat agar komunikasi berjalan dengan baik adalah adanya Bahasa (Ardana, 2019), dan akan selalu digunakan oleh masyarakat luas hingga luar daerah pulau jawa dalam berkomunikasi. Bahasa Jawa merupakan suatu bahasa daerah yang sangat perlu dilestarikan supaya tidak hilang keberadaannya.

Pada tutur dalam Bahasa jawa terdapat banyak tingkat tutur dan terlihatnya tingkat tutur sudah diperkirakan pada abad ke-17, tepatnya pada zaman Raja Sultan Agung (1613-1645), yaitu pada zaman kerajaaan Mataram (Budiono et al., 2018). Namun adanya tingkat tutur tersebut sudah ada pada abad ke-15 yaitu pada periode pertengahan, yang munculnya terdapat tulisan Dewaruci Tembang Gedhe. Walaupun sudah terlihat pada abad ke-15, tapi khususnya tutur kata krama inggil sudah ada pada zaman kuno atau dalam bahasa Jawa kuno (Wilian, 2006).

Tingkat tutur ngoko adalah variasi bahasa dengan kosakata ngoko yang digunakan untuk berkomunikasi dengan yang sudah akrab seperti teman atau dengan pergaulan yang sama (Suryadi, 2013), bahasa ini mencerminkan rasa tidak berjarak atau bahasa pergaulan yang di pakai sehari-hari.

Ragam bahasa Jawa ngoko adalah leksikon Ngoko unggah ungguh. Imbuhan yang muncul dalam ragam ngoko menggunakan -e, di-, dan -ake. Ragam Bahasa ngoko dapat dibedakan menjadi dua yaitu ngoko alus dan ngoko lugu

Ngoko: "dhẻwẻkẽ khanda yẽn wong tuwanẻ ora bisa tindak mrẻnẻ".

Madya: "Piyambakẻ criyos yẻn tiyang sepuhẻ mboten saged mriki".

yang artinya: "dia berkata bawa orang tuanya tidak bisa datang kesini"

Penggnaan media online yang berbahasa Jawa meningkat pada saat Indonesia mengalami Corona Virus Disease 2019 yang disingkat dengan COVID 19 meningkat pesat. Akibat Covid pada segala sector menurun drastic seperti UMKMmakanan dan minuman $27 \%$, konsumsi rumah terkoreksi sampai 0.5 $0.7 \%$, sedangkan penggunaan teklnologi meningkat sampai 85\% (Amri, 2020). Berdasarkan fenomena COVID 19, peneliti bersemangat untuk mengambangkan koreksi bahasa Indonesia ke Bahasa Jawa agar memudahkan penggunaan Bahasa jawa via media online. Disamping itu, penelitian ini bertujuan untuk mengetahui seberapa cepat tingkat ke-akurasian dengan metode Levenshtein Distance. Pada penelitian ini dibangunlah sistem untuk mempermudah pengembang agar lebih fleksibel dalam mengembangkan p-ISSN : 2502-5724; e-ISSN : 2541-5735 
aplikasinya tanpa memandang berbagai platform dan Bahasa pemrograman yang digunakan yang digunakan.

\section{METODELOGI}

\subsection{Data Penelitian}

Data yang digunakan pada penelitian Implementasi Algoritma Levenshtein Distance Dengan Restful Web Service Pada Kata Bahasa Indonesia Ke Bahasa Jawa Berbasis Website yang terdiri dari 172 kata yang diambil dari website dongengceritarakyat.com.

\subsection{Masukkan query client}

Pada tahap ini akan dimasukkan query client untuk mencari hasil terjemah dari kalimat bahasa Indonesia ke bahasa Jawa. Pertama, memasukkan daftar kata dari Tabel 4.1.

\subsection{Hasil proses}

Proses terahir dari sistem adalah, menampilkan hasil query dari input client. Sehingga dapat diketahui apakah input dari client terdeteksi atau tidak terdeteksi oleh metode Levenshtein Distance dalam pencocokan kata yang ditargetkan. Apabila kata tersebut terdeteksi oleh metode, maka akan ditampilkan sugesti hasil kata oleh sistem.

\section{HASIL DAN PEMBAHASAN}

Sebagai peneliti tentunya ingin mengetahui input, proses dan output dari algoritma levensthein distance. Untuk mendeteksi kemiripan dan kebenaran dalam menterjemah Bahasa Indonesia ke Bahasa Jawa berbasis web peneliti mengembangkan source code, input data penelitian, menjalankan program, dan menganilis hasil program menggunakan confusion matrix.

\subsection{Source code yang digunakan}

Berikut merupakan sourch code Levenstein Distance dan beserta fungsinya yaitu:

$$
\begin{aligned}
& \text { 1. <?php } \\
& \text { 2. class BackEndLevenshtein\{ } \\
& \text { 3. function dapatkanNilailevensthe } \\
& \text { in(\$stringInput, \$stringTujuan)\{ } \\
& \text { 4. } / / \text { \$jarakAntarPrefixes }=[\mathrm{c} \\
& \text { 5. \$jarakAntarPrefixes = array } \\
& \text { ( ) ; } \\
& \text { 6. for }(\$ i=0 ; \$ i<\text { strlen( } \$ \text { stringI }
\end{aligned}
$$

Sourch code tersebut merupakan pengambilan nilai minimum levenstein distance, yang akan di eksekusi untuk di ambil percobaan pencocokan kata sebelum di terjemahkan ke Bahasa jawa.

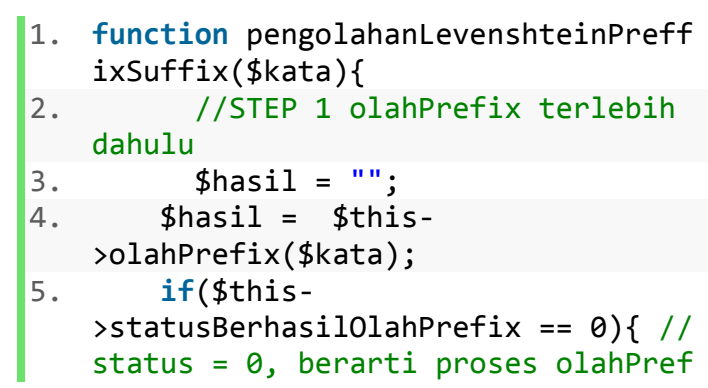




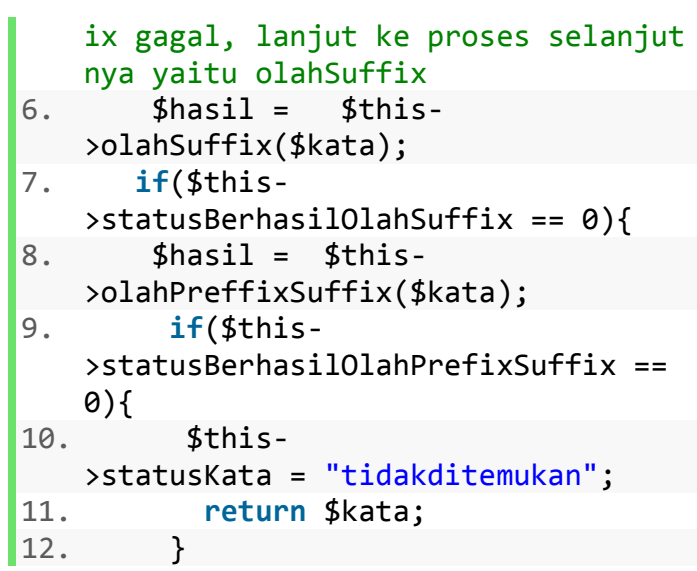

Source code di atas merupakan sourch code pengolahan prefix awalan kata imbuhan dan suffix atau ahiran kata levenstein distance. Dan sebelum user memasukkan kata yang akan di terjemahkan ke Bahasa jawa maka kata tersebut di sortir apakah mengandung prefix atau suffix yang salah. Jika prefix dan suffix itu salah maka akan di proses oleh metode levenstein disntace.
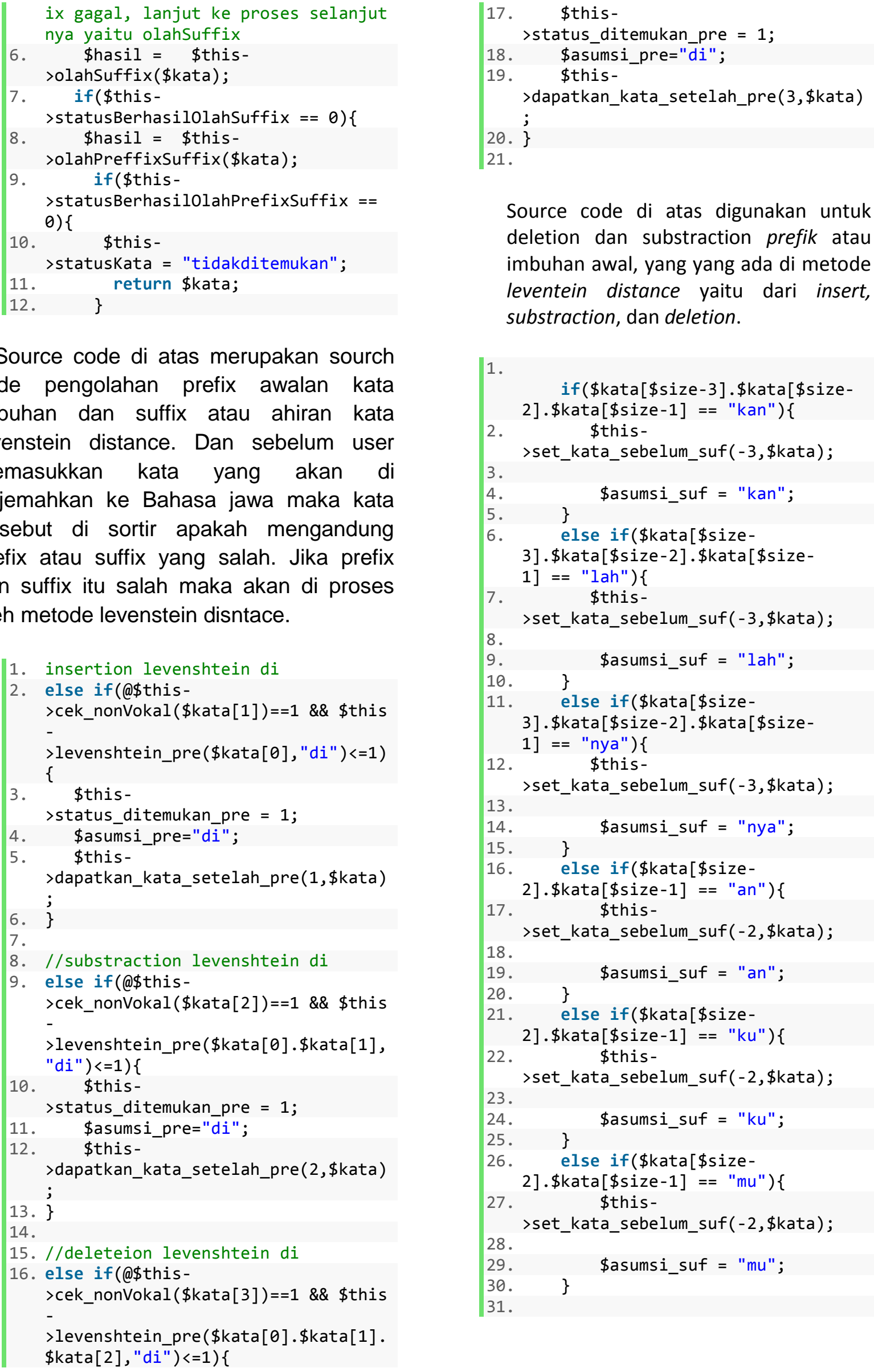

Source code di atas digunakan untuk deletion dan substraction prefik atau imbuhan awal, yang yang ada di metode leventein distance yaitu dari insert, substraction, dan deletion.

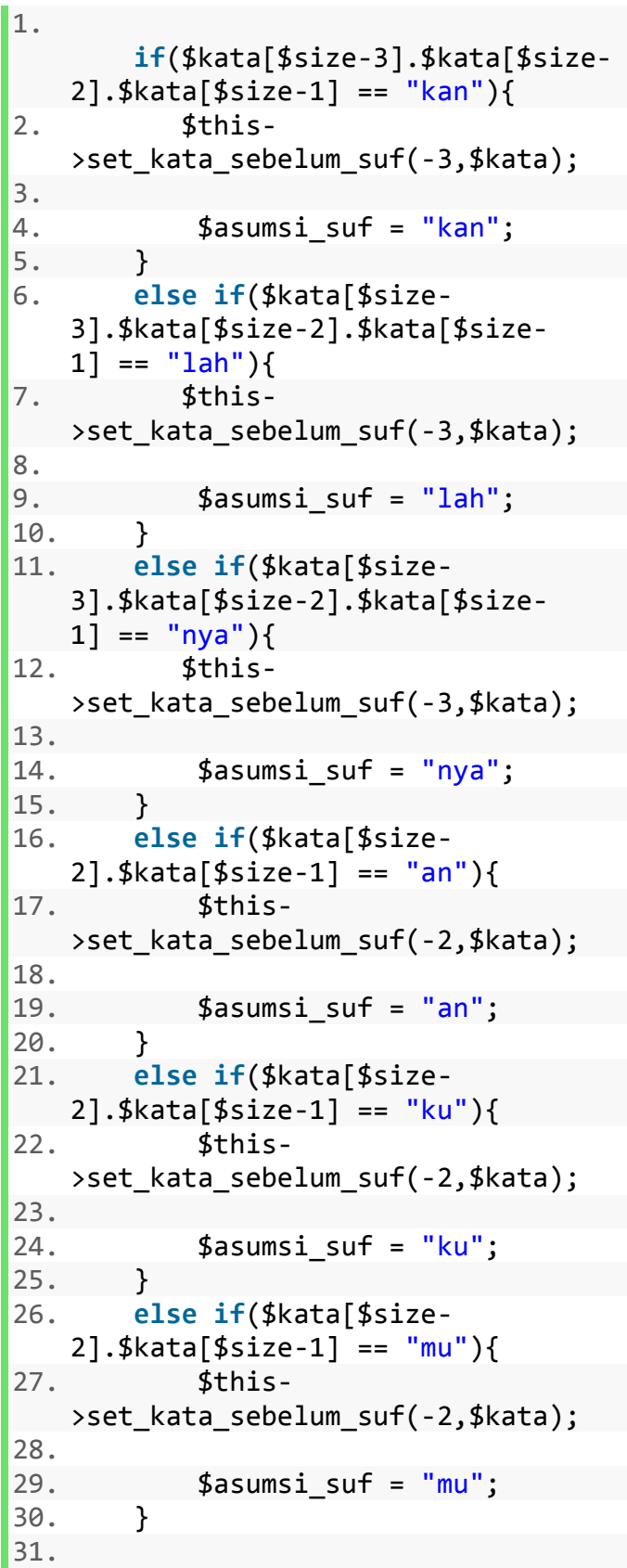


Source code di atas digunakan untuk sufix contoh kata ahiran dalam pemrosesan levenstein distance.

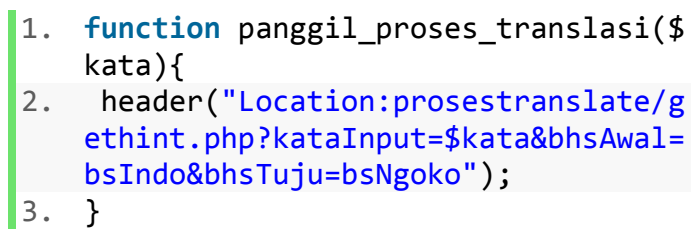

Source code di atas merupakan function pemanggilan Bahasa jawa ngoko yang akan di translisasikan dari Bahasa Indonesia ke Bahasa Jawa Ngoko.

Adapun pseudocode dari algoritma levenshtein distance (Ilmy et al., 2006) adalah adalah sebagai berikut:

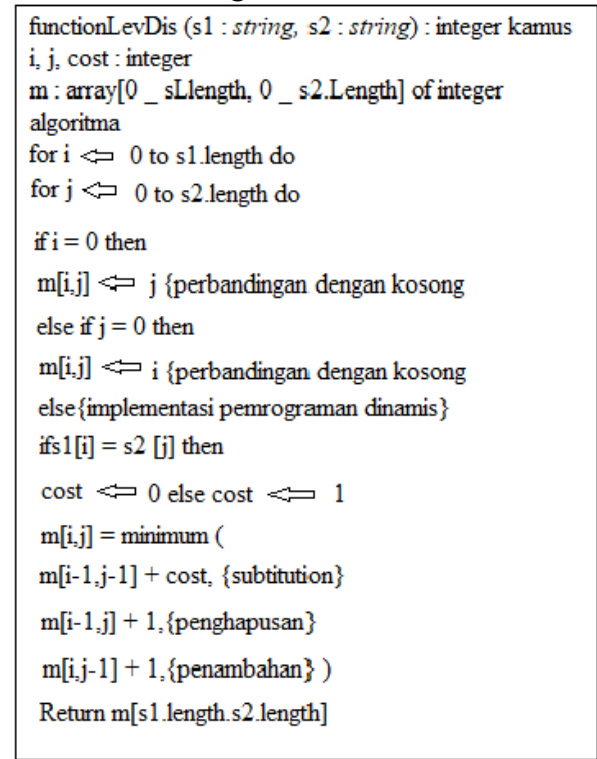

Gambar 5. Pseudocode dari Algoritma Levenshtein distance

\subsection{Hasil Output program}

Untuk mengetahui aplikasi yang dibuat apakah sudah sesuai dengan membandingkan hasil dari sumber input dan target output yang diinginkan.

\subsection{Confusion matrix}

Untuk melihat akurasi dan presisi peneliti menggunakan confusion matrix. Matrik klasifikasi adalah alat yang memiliki fungsi untuk melakukan analisis prediksi benar dan tidak benarnya oleh model klasifikasi yang berbeda (Leidiana, 2013).
Pada tahap uji coba menggunakan confusion matrix yang berguna untuk mengetahui sistem sudah berfungsi sudah sesuai dengan perancangan yang sebelumnya. Pengujian sistem dilakukan dengan cara membandingkan hasil terjemah bahasa Jawa secara manual (groundtruth). Dengan hasil terjemah bahasa Jawa yang secara otomatis ditampilkan oleh sistem. Data untuk di terjemahkan ke bahasa Jawa yang digunakan yaitu pada sub bab sebelumnya, dengan mengambil data dari kalimat yang terdiri 172 kata, yang diambil dari cerita dongeng si kancil dan si buaya dari website yang terkenal yaitu dongengceritarakyat.com, dan dengan sebanyak kosakata yang di sediakan oleh sistem pada database dalam pernerjemahan terdapat pada Tabel 10. Berikut:

Tabel 4 Database kosakata Bahasa Indonesia dan Bahasa Jawa

\begin{tabular}{|c|c|c|c|c|}
\hline \multicolumn{5}{|c|}{ Kosakata bahasa jawa yang ada di database } \\
\hline Ae & elek & icip & saben & yaiku \\
\hline Abang & eling & idu & sabut & yais \\
\hline Aboh & embah & ijo & sabun & yatim \\
\hline Abot & embuh & $\ldots .$. & saiki & yen \\
\hline$\ldots .$. & $\ldots .$. & $\ldots .$. & $\ldots .$. & yo \\
\hline Babu & gampang & $\ldots .$. & udan & $\ldots .$. \\
\hline Babah & garing & ogah & udar & zaman \\
\hline Babak & gatek & ombe & udek & zamin \\
\hline Babakan & gawa & opah & udel & $\begin{array}{c}\text { zamin } \\
\text { dar }\end{array}$ \\
\hline Total kosakata dalam database: 30382 \\
\hline
\end{tabular}


Keterangan: Jumlah kata yang ada di database sebanyak 30382 kata.

Rumus confusion matrix pada tabel 5 Berikut;

Tabel 5 Confusion Matrix

\begin{tabular}{|c|c|c|c|}
\hline & & \multicolumn{2}{|c|}{ Rumus Hasil } \\
\hline & & TRUE & FALSE \\
\hline $\begin{array}{c}\text { Nilai } \\
\text { Prediltif }\end{array}$ & TRUE & $\begin{array}{c}\text { TP } \\
\text { (True } \\
\text { Positif) }\end{array}$ & $\begin{array}{c}\text { FP } \\
\text { (False } \\
\text { Positif) }\end{array}$ \\
\hline & FALSE & $\begin{array}{c}\text { FN } \\
\text { (False } \\
\text { Negatif }\end{array}$ & $\begin{array}{c}\text { TN } \\
\text { (True } \\
\text { Negatif })\end{array}$ \\
\hline
\end{tabular}

Keterangan:

1. True Positive (TP): jumlah record yang memberikan hasil sesuai dengan query dan memang benar sesuai.

2. False Positive (FP): jumlah record yang memberikan hasil prediksi sesuai dengan query, akan tetapi tidak sesuai setelah di cek oleh (manusia).

3. True Negative (TN): jumlah record yang seharusnya memberikan prediksi tidak sesuai dengan query dan memang sebenarnya tidak sesuai.

4. False Negative (FN): jumlah record yang memprediksi tidak sesuai dengan query, tapi menurut (manusia) memang sesuai.

Berdasarkan Tabel tersebut, precision, recall dan accuracy dapat dirumuskan dengan persamaan berikut:

$$
\begin{gathered}
\text { Precision }=\frac{a}{a+b} \times 100 \% \\
\text { Recall }=\frac{a}{a+c} \times 100 \% \\
\text { Accuracy }=\frac{a+d}{a+b+c+d} \times 100 \% \\
\begin{array}{l}
\text { F- measure }=2 \times \\
\text { precision } \times \text { recall } \\
\text { precision }+ \text { recall }
\end{array}
\end{gathered}
$$

F-measure merupakan bobot dari precision dan recall yang merupakan ukuran timbal balik di antara keduanya.

Uji coba sistem dilakukan dengan menggunakan data sejumlah dua belas query yang berbeda. Dari dua belas query, akan didapatkan tujuh hingga tiga puluh dua kemungkinan nilai tertinggi sebagai prediksi jawaban terjemah bahasa Indonesia-Jawa. Dari masing-masing query yang berhasil di input-kan,

Dapat dilihat hasil dari pengujian confusion matrix pada table 6 .

Tabel 6. Hasil Pengukuran precision, recall, $f$-measure, dan accuracy

\begin{tabular}{|c|c|c|c|}
\hline Precision & Recall & Accuracy & $\begin{array}{c}\text { F- } \\
\text { measure }\end{array}$ \\
\hline $95,32 \%$ & $100 \%$ & $99,97 \%$ & $97,52 \%$ \\
\hline
\end{tabular}

Berdasarkan hasil uji coba yang telah dilakukan, query answering system tanaman obat ini memiliki tingkat keakurasian mencapai $87.91 \%$. Adapun beberapa masalah dan penyebab ketidakakuratan yang terjadi di dalam sistem ini adalah sebagai berikut:

Berdasarkan hasil pengujian dengan uji coba sebanyak jumlah input yang dilakukan, dapat disimpulkan bahwa penggunaan metode approximate string matching dalam pembetulan kata bahasa Indonesia sebelum di terjemahkan ke bahasa Jawa tidak terdapat banyak kesalahan proses dan secara fungsional menghasilkan dengan benar sesuai sumber input dan target output pada proses approximate string matching tersebut. Dan proses terjemah sesuai dengan input bahasa Indonesia dan output bahasa Jawa sesuai yang diharapkan.

\section{KESIMPULAN}

Berdasasarkan alur uji coba yang dilakukan oleh peneliti dengan judul Implementasi Algoritma Levenshtein Distance Dengan Restful Web Service Pada Kata Bahasa Indonesia Ke Bahasa Jawa Berbasis Web, dengan uji coba data sejumlah 172 kata, dan sebanyak 30.382 kosakata yang ada di database. Dapat 
ditarik kesimpulan bahwa:

1. Pengujian dilakukan terhadap dua belas query, didapatkan hasil persentase nilai precision sebesar $95,32 \%$, nilai recall $100 \%$, nilai accuracy $99,97 \%$, dan nilai $f$ measure $97,51 \%$

2.Penggunaan metode Levenshtein Distance pada query sebanyak dua belas query berdasarkan input sumber dan output target dikatakan efektif karena mendapatkan persentase yang cukup tinggi.

3. Tidak terdapat banyak kesalahan pada proses, sehingga secara fungsional dapat menampilkan hasil yang sesuai harapan.

Adapun saran bagi peneliti selanjutnya adalah:

1. Perlu adanya improvement pada metode Approximate String Matching dengan algoritma levenstein distance yaitu membuat perbedaan bobot atau nilai antara penyisipan, penghapusan, dan penggantian karakter. Perbedaan bobot juga dapat dikembangkan lagi dengan melihat letak penyisipan, penghapusan, atau penggantian karakter yang terjadi. Yang dimaksud bobot perbedaan yaitu bertujuan untuk mendapatkan variasi yang mirip dari query yang asli.

2. Penerapan metode Levenshtein Distance pada penerjemah IndonesiaJawa dengan pembetulan kata dapat juga dikombinasikan dengan algoritma lain yang berhubungan dengan pencarian similarity antar dua buah kata misalnya algoritma $\mathrm{N}$-Gram atau Knuth Morris Pratt (KMP). Sehingga didapatkan variasi yang lebih relevan dengan query asli.

\section{DAFTAR PUSTAKA}

Amri, A. (2020). DAMPAK COVID-19 TERHADAP UMKM DI INDONESIA. BRAND Jurnal IImiah Manajemen

p-ISSN : 2502-5724; e-ISSN : 2541-5735
Pemasaran, 2(1), 123-131.

Ardana, D. M. J. (2019). PERANAN KOMUNIKASI STAF DALAM SOSIALISASI PROGRAM KERJA DI PUSKESMAS TEJAKULA II KECAMATAN TEJAKULA. Locus, 11(1).

Arisandy, D., Rizkika, D. P., \& Astika, T. D. (2019). EKSISTENSI BAHASA INDONESIA PADA GENERASI MILENIAL DI ERA INDUSTRI 4.0. Bahastra: Jurnal Pendidikan Bahasa Dan Sastra Indonesia, 3(2), 247-251.

Budiono, S., Erikha, F., \& Pahlevi, E. R. (2018). Penelusuran Hubungan Bahasa Jawa Dialek Banyumas dengan Bahasa Jawa Dialek Banyuwangi Berdasarkan Variasi Bahasa Jawa Relationship Identification Banyumas Dialect in Central Java with Banyuwangi Dialect in East Java Based on Javanese Variation.

Dwitiyastuti, R. N., Muttaqin, A., \& Aswin, M. (2013). Pengoreksi Kesalahan Ejaan Bahasa Indonesia Menggunakan Metode Levenshtein Distance. Jurnal Mahasiswa TEUB, 1(2).

Ilmy, M. B., Rahmi, N., \& Bu'ulölö, R. L. (2006). Penerapan Algoritma Levenshtein Distance untuk Mengoreksi Kesalahan Pengejaan pada Editor Teks. Departemen Teknik Informatika, Institut Teknologi Bandung.

Indra, Z., \& Trisnawati, L. (2018). Pengembangan intelligent data collector untuk analisis big data artikel berita online. Rabit: Jurnal Teknologi Dan Sistem Informasi Univrab, 3(1), 47-57.

Leidiana, H. (2013). Penerapan algoritma k-nearest neighbor untuk penentuan resiko kredit kepemilikan kendaraan bemotor. PIKSEL: Penelitian IImu Komputer Sistem Embedded and Logic, 1(1), 65-76.

Noerwidi, S. (2008). Awal Pendaratan Austronesia di Pantai Utara Jawa, Sebuah Prospek Melacak Nenek Moyang Etnis Jawa. Pertemuan IImiah Arkeologi XI.

Peggy, P. (2014). Optimasi pencarian kata 
Welly Kuswanto, Implementasi Algoritma Levensthein Distance dengan... hlm 78-85

pada aplikasi penerjemah bahasa mandarin-indonesia berbasis android dengan algoritma levenshtein distance. Universitas Multimedia Nusantara.

Rifa'i, A. M. (2015). Nasionalisme dalam Perspektif Bahasa Sebagai Perwujudan Jati Diri Bangsa. AlMabsut: Jurnal Studi Islam Dan Sosial, 9(2), 155-180.

Suryadi, M. (2013). Penggunaan Tingkat Tutur Bahasa Jawa Ngoko dan Krama pada Ranah Keluarga dan Masyarakat di Kota Semarang dan Kota Pekalongan. UNS (Sebelas Maret University).

Wilian, S. (2006). Tingkat tutur dalam bahasa Sasak dan bahasa Jawa. Wacana, 8(1), 32-53. 